\title{
A Note to the Reader
}

Quotations from Pamela are from the following two editions: Pamela, or, Virtue Rewarded, ed. T. C. Duncan Eaves and Ben D. Kimpel (Boston: Houghton Mifflin, 1972); and Pamela [Volume 2] (London and New York: Dent Dutton, 1978). The first is a reprint of the first ( 1740 ) edition of Pamela, with the letters of praise and Richardson's response to criticism (the "Introduction to the Second Edition") added. The second is Richardson's continuation of Pamela (I74I), usually referred to as "Part 2." Quotations from Pamela cite simply the page number: "I have been in Disguise indeed ever since my good Lady, your Mother, took me from my poor Parents" (p. 62).

Quotations from Clarissa follow the text of the third edition: Clarissa. Or, the History of a Young Lady, 8 vols. (New York: AMS Press, I990; rpt. of 3 d ed., I75I). After the volume and page number, though, I also cite the page number for the equivalent passage in the widely available and inexpensive Viking Penguin Clarissa, edited by Angus Ross (Harmondsworth, Eng.: Penguin, I985), a lightly modernized version of the first edition (I 74748). I have also indicated in notes those passages I quote that do not appear in the first edition. Quotations from Clarissa appear as in the following example: "And hence it is, that a mischief which would end in simple robbery among men rogues, becomes murder if a woman be in it" (V: 3I4) (896).

For The History of Sir Charles Grandison, I use the Oxford Clas- 
sics paperback based on the first edition of 1753-54, edited by Jocelyn Harris (Oxford: Oxford Univ. Press, 1986), which reprints the 1972 three-part edition in a single volume. The citations are to part number and page number. "The best of men, they said, loved to have difficulties to conquer. Their brother, generous as he was, was a man" (I.423).

In the texts of all three novels, Richardson occasionally uses square brackets along with parentheses; in order to distinguish Richardson's brackets from my own in quotations, I have added the words "brackets in original" where necessary. 
Samuel Richardson's

Fictions of Gender 
